\title{
Kernos
}

Revue internationale et pluridisciplinaire de religion grecque antique

20 | 2007

Varia

\section{Pherekydes' Daktyloi}

Ritual, technology, and the Presocratic perspective

\section{Sandra Blakely}

\section{(2) OpenEdition \\ 1 Journals}

\section{Electronic version}

URL: https://journals.openedition.org/kernos/161

DOI: 10.4000/kernos.161

ISSN: 2034-7871

\section{Publisher}

Centre international d'étude de la religion grecque antique

\section{Printed version}

Date of publication: 1 January 2007

Number of pages: $43-67$

ISSN: 0776-3824

\section{Electronic reference}

Sandra Blakely, "Pherekydes' Daktyloi", Kernos [Online], 20 | 2007, Online since 15 March 2011.

connection on 08 September 2022. URL: http://journals.openedition.org/kernos/161 ; DOI: https:// doi.org/10.4000/kernos.161

This text was automatically generated on 8 September 2022.

All rights reserved 


\section{Pherekydes' Daktyloi}

Ritual, technology, and the Presocratic perspective

\section{Sandra Blakely}

\section{Introduction: Classics and the Evolutionary paradigm}

1 Western culture is traditionally ill equipped to understand the intersection of ritual and technology. Pfaffenberger, Killick, and Lansing have observed the causes, and what is lost by failing to shake these off. ${ }^{1}$ Because these activities occupy different categories in the industrialized world, attempts to interpret their coincidence in other cultures lean to the dismissive. They are regarded as a reflection of the earliest stages of invention, compensatory appeals to the divine that reflect incomplete mastery of technological processes. The combination is often called magic by both practitioners and academics. Magic has been traditionally synonymous with primitivism; an evolutionary model suggests that such superstitions evaporate as technology is mastered, and linger only in folk tales and half-remembered superstitions. ${ }^{2}$ The cost of this paradigm is substantial. Emphasizing the movement into subsequent intellectual paradigms, it reduces attention to symbols in context. Overlooking the complexity of ritual actions, it reduces them to mnemonic devices and apotropaia. And assuming that crafting gods are worshipped by crafters, it obscures the role of the technological sema in a culture's self-identification. The intersection of the supernatural and the pragmatic articulates the relationship between cosmology, economy, environment, and history. Its relevance reaches beyond the craft's practitioners; it is to be investigated less as a professional secret than a culturally embedded system.

2 The Idaian Daktyloi, in Greek tradition, have exemplified these tendencies. Inventors of iron and also magicians, they hover in fragmentarily preserved texts at the moment of first invention but never translate into the literary canon or civic cult. ${ }^{3}$ The noncanonical record is characteristically interpreted as a signal of minor cultural significance, reinforced by their identification as daimones and thus categorized with folk tradition and minor gods. ${ }^{4}$ Their mythological association with the first emergence of iron has been taken literally, so that they seemed primitive in both chronological 
and evolutionary terms. They appear in scholarship as archaic daimones and magiciansmiths, compared to the dwarves of European folk tradition or the Siberian shamans who encountered demonic ironsmiths in the course of their initiations. ${ }^{5}$ These studies are informed by the anthropology of their time, which was evolutionary and primitivistic. The same perspective informed classical studies in their regard for Presocratic thought. Operating under the spell of Aristotle, these regarded the Presocratic combination of science and magic as inelegant fumbling toward scientific procedures. ${ }^{6}$ Their taxonomies were more aesthetic than accurate; their blend of myth and rationality was a mark of primitivism, and an index of their inefficiency as tools for thinking.

3 Burkert, Lloyd, Kingsley, Dickie and others have helped revolutionize this estimation of the sixth-century sages, exploring the cultural potency of the goes who was the master of science as well as magic, and the intersection of these endeavors in the ancient Greek context. ${ }^{7}$ The Daktyloi's blend of goeteia and the apparent banalities of mining and metal production, however, remains trapped in a developmental perspective. Little in scholarship has moved beyond the primitivism and evolutionism that informed Delcourt's study of Hephaistos as a magician, in which she argued that magic evaporated as technology was mastered. This is despite notable advances in the study of ancient magic which counter its relegation to the earliest stages of Greek culture, or the lowest strata of ancient society. This may reflect the Athenocentrism of text based studies, extrapolating a general anti-banausic sentiment from Hephaistos' deformity. Hesiod's dim view of iron's arrival has characteristically been invoked as an explanation for the poorly preserved and negatively perceived daimones who invented it. $^{8}$ Both of these perceptions betray a reliance on canon rather than context, and on a developmental trajectory of the type over time, rather than on the connections within the Idaian Daktyloi as a mythological type.

4 The daimones in question have testimonia that stretch over 1300 years of Greek history, in thirty one thinly scattered citations. A single paradigm of meaning for their intersection of magic and technology is unlikely, particularly one that relies on the survival of suspicious reactions to new technologies. ${ }^{9} \mathrm{~A}$ more nuanced set of interpretations can be established using three principles from recent anthropologies of technology. The first is that narratives of invention reflect historical memory less than they do current realities. ${ }^{10}$ This offers a more contextualized approach to the evidence for the daimones, one that balances their identification as archaic with the much later dates of most of their evidence. A second principle is that technological sema derive their meaning not simply from the technologies to which they refer, but from the integration of that sign into the cultural fabric. ${ }^{11}$ The latter includes cosmology, economy, ecology, ritual and theology. An analysis focused on the concerns of workers alone overlooks the goal of integration that the technological sema enables, and the wide range of meanings that may emerge. This has, however, been the typical approach to the question of the Daktyloi, who have since the $18^{\text {th }}$ century been interpreted largely in terms of their reference to the historical reality of ironworkers. The range of texts in which the Idaian Daktyloi appear is broad and varied, including epic, comedy, hymns and proverbs. These were neither created nor heeded exclusively by artisans, and the variation in genre and audience encourages consideration of a broad range of meanings. This points to the third essential anthropological principle: attention to the ethnographic informant. Different informants even within a single geographical area 
and time frame offer varying reasons for the same phenomenon. We should expect no less from the literary fragments from antiquity.

These principles may be applied with good effect to one of the earliest pieces of evidence for the Idaian Daktyloi. This is a fragmentum incertum which Jacoby assigned, with some hesitation, to the Athenian Pherekydes. The context of the fragment suggests the magical powers claimed by Presocratic sages; the content of the fragment suggests a striving toward the table of opposites attributed to the Pythagoreans and their predecessors. I begin with an introduction to the fragment, its attribution, and its context as a scholiast's commentary to Apollonios of Rhodes' Argonautica. These suggest that the Daktyloi were more a model for Presocratic thinkers than for smiths. Consideration of the possible authorship by Pherekydes of Syros, rather than the Athenian Pherekydes, invites an exploration of the Presocratic uses of these daimones as image and myth in ritual context. While previous models for the daimones' goeteia focused on telluric iron and the mysteries of its production, thinkers employing a Pythagorean tradition found more use for celestial metal, which informs their observations on the Ephesian Letters and the mysteries of Cretan Zeus. Examination of these rituals, proper to the goetes, demonstrates their integration into a wide range of historical, ritual and mythological types. This suggests a greater relevance for these fragmentarily preserved daimones than can be apprehended by focusing on smithing alone.

\title{
Attribution
}

\author{
Pherekydes von Athen FGrH 3 F 47 Jacoby

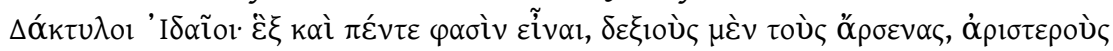

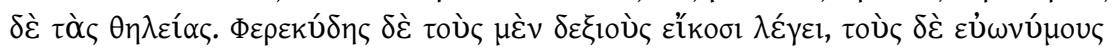

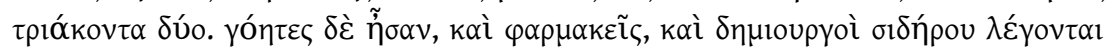

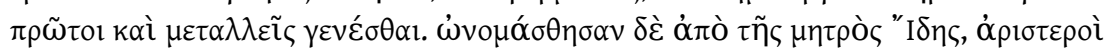

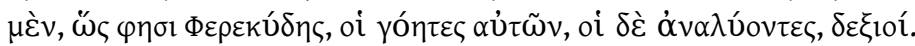 \\ Idaian Daktyloi: They say they are six and five, the right being male, the left being \\ female. Pherekydes says the right are twenty, and the left thirty two. They are \\ magicians and poisoners, and they are said to be the first skilled workmen in iron \\ and to be miners. They are named for mother Ida, the left of them, as Pherekydes \\ says, are magicians, and those loosening spells the right. ${ }^{12}$
}

6 This fragment of Pherekydes was preserved in the scholiast to Apollonios of Rhodes' Argonautica. This scholiast is one of the richest sources of information on the Idaian Daktyloi. In addition to this fragment of Pherekydes, he recorded the observations of Stesimbrotos, Sophokles, Hellanikos, Mnaseas, and the author of the Phoronis, as well as the opinions of Maiandros the Milesian, Kallistratos, Promethidas and Theophanes regarding the Idaian Daktyloi called Titias and Kyllenos. Which Pherekydes was meant is not certain: no less than five are known, including a Lyrian, an Athenian author of a work on autochthones, an astrologer, and those to whom the bulk of the testimonia belong. These are the Athenian, Pherekydes Historicus, and Pherekydes of Syros, known as the first prose writer of Greece. ${ }^{13}$

7 Jacoby assigned this passage to the Athenian, arguing that he is most often cited by the Argonautica's scholiast, and that he tends to provide details in support of heroic myth; Schibli and West agree. Bulloch takes the opposite approach, asserting that the Syrian Pherekydes was a frequent source for the scholiast, and generally well informed about 
matters relevant to the Argonautica. ${ }^{14}$ Jacoby himself was uncertain, observing that the fragment does not fit into the human, heroic pedigrees that were the Athenian's concern, any more than do the other fragments concerning similar deities such as Kyklopes, Kabeiroi, and Hekate. Wilamowitz suggested that the level of mythological erudition in the excerpt seems more appropriate to Apollodoros. ${ }^{15}$ Neither geographical references, nor a recognizable historical event, suggest a firmer attribution.

Resonances with Presocratic thought recommend consideration of the Syrian Pherekydes, whom tradition identified as the teacher of Pythagoras. The tradition has limited value as historical fact, but indexes the general perception of similarities between the two men, their teachings and their work. ${ }^{16}$ Diels used thematic parallels of this nature to assign a fragment to Pherekydes of Syros rather than the Athenian. ${ }^{17}$ It is an imagistic parallel that recommends reconsideration in the case of this fragment - a unique employment of the imagery of the hand. The "finger" name of the Daktyloi encouraged folk etymologies, puns and allegorical speculation in the ancient world, comparing them to mountain foothills, craftsmen's hands, Rhea's handprint or the fingers of Zeus' nurses. ${ }^{18}$ This fragment represents the only attempt to elaborate distinctions between right and left Daktyloi, aligning the orientations with the opposition between male and female, binding and loosening, and asymmetrical numbers that violate the symmetry implied in the body imagery. Aristotle was the first to formalize these into a table, and attributed it to the Pythagoreans. ${ }^{19}$ This sustoichia consisted of a left column including odd, one, right, male, and good, and a right column of even, plurality, left, female, and bad. Attention to paired opposites was widely recognized for its rhetorical effectiveness, and an extremely old device; the Pythagoreans were unique in considering it an accurate reflection of cosmic order. ${ }^{20}$ Lloyd notes that the ideas in the table appear in Pythagorean akousmata, in the writings of later Platonists, and in pseudo-Pythagorean works. ${ }^{21}$ While their presence alone is not enough to affirm a specific authorship, their association with Presocratic thought recommends Pherekydes of Syros above his Athenian counterpart.

The texts conventionally assigned to the Syrian show little resonance with this fragmenta incerta, or with scientific schemes of order. They offer a mythological cosmogony in which Chronos, Chthonie and Zas are primary elements, the sperm of Chronos yields the generation of gods, and a divine marriage, a cosmic robe, a battle against a serpent, and a division of honors complete the narrative. ${ }^{22}$ It is not this text, but the authorial tradition, that most suggests an interest in the physical world, the scientific spirit, and the Ionian rationalism which Jacoby considers the greatest distinction between the Syrian and the Athenian Pherekydes. ${ }^{23}$ Aristotle noted that the Syrian Pherekydes did not write "completely mythologically;" Diogenes Laertius cites Theopompos that he was the first to write about nature and gods; Cicero referred to him as a natural philosopher, physicus; Flavius Josephus placed him among the Greeks who first philosophized about matters celestial and divine, in the company of Pythagoras and Thales, with whom he undertook Egyptian and Chaldean studies. ${ }^{24}$ The lateness of these testimonia should not encourage their dismissal: Graf, Dickie, Thom and Kingsley caution against too firm an insistence on the dating of Pythagorean tradition, and note that relatively late material is often considered to be based on much earlier traditions. ${ }^{25} \mathrm{An}$ argumentum ex silencio based on the extant fragments would reduce the complexity of the authorial type whose use of both mythic traditions and scientific thought was well established by the time of the Argonautica's scholiast. The goeteia of this fragment has little resonance with the work of Athenian Pherekydes, but 
suits both the authorial type and the cosmological concerns of Pherekydes of Syros. Thepassage that prompted the fragment's preservation, moreover, offers light on the ritual powers encompassed by the Daktyloi's goeteia, and associated as well with Presocratic sages.

\section{Daktyloi and goeteia}

10 Pherekydes' fragment was preserved in response to the Argonauts' execution of a ritual that controls the weather, soothes the dead, and evokes terrestrial fecundity. All of these fall within the range of powers appropriate for the goes. The Argonauts have accidentally killed their host Kyzikos, a situation demanding the goes' abilities to soothe the dead. The centrality of this power to their character may be noted in the popular etymology of their title from goos, the lament for the dead. ${ }^{26}$ Great storms arise that hinder the Argonauts' voyage. Power over the weather is another important aspect of the goes' power: Empedocles offers a detailed description of how he used his knowledge to calm the storms and so save the crops, using bags made of asses' hides to hold the wind. ${ }^{27}$ Similar powers were attributed to Demokritos and to Plato, who were considered to have learned the skills of the Persian Magi and Chaldaians. The Telchines' weather powers were likened to these Persian prototypes, of whom Diodorus Siculus reports that they could stir up clouds, rain, hail and even snow. ${ }^{28}$ The Argonauts' predicament is answered by a dream that comes to Mopsos the seer, which explains the proper ritual response to their situation. He directs the men to climb Mount Dindymum to the temple of the mother. They cut down a "sturdy stump of vine" and smooth it, creating a sacred image of the xoanon type ${ }^{29}$ They build an altar and put oak crowns on their heads. Jason performs a sacrifice to the mother and to the Idaian Daktyloi named Titias and Kyllenos, whom Apollonios identifies as dispensers of doom, attendants on the Idaian mother, Cretan Daktyloi born of the nymph Anchiale in the Diktaian cave. As Jason sacrifices, the men, led by Orpheus, execute an armed dance, clashing swords on shields to hide the sounds of mourning for the slain king.

11 The results of the dance exceed the need to calm the storm. The goddess makes the trees bear fruit, the earth put forth flowers, a stream of water burst forth from Dindymum, and wild beasts, suddenly tamed and wagging their tails, approach the men. Control over the earth's fecundity is a natural concomitant of weather magic, which was as often exercised to ensure the success of crops as to protect travelers at sea. ${ }^{30}$ The Argonauts thus achieve the goals for which goetes are usually summoned. The scholiast seems concerned to demonstrate the appropriateness of the Daktyloi in this context. He offers two passages affirming the Daktyl's identification as goetes, the Pherekydes cited above as well as five lines of the Argive epic, the Phoronis. The Phoronis describes the Daktyloi as goetes, mountain-dwelling men of Phrygia, ingenious attendants on the mountain mother Adrasteia, who discover the works of Hephaistos. They work iron described in Homeric terms, shining and violet-colored, and are named Kelmis, Damnameneus, and Akmon. Both the Phoronis and Pherekydes affirm that the Argonaut's invocation of the Cretan Daktyloi ensures the presence of the goetes whose ritual powers the group successfully exercises. The iron that the Phoronis and Pherekydes also mention, however, has no counterpart in the Argonauts' performance, and its logic must be sought elsewhere. 
Kelmis, one of the brothers introduced in the Phoronis, is the protagonist in a story that has long been considered the heart of metallurgical mysteries. A familiar proverb,

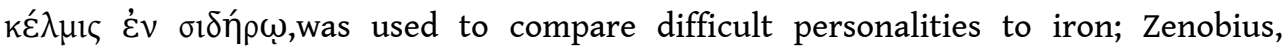
Sophokles, and the scholiast to Nikander's Theriaka offer the outlines of the story behind it. ${ }^{31}$ Kelmis offended the Great Mother in some unspecified way. As punishment, his brothers confined him deep beneath Mount Ida, where he metamorphized into the iron that embodied his unyielding personality. Rossignol, writing in 1863, saw in this account the traces of metallurgically focused mysteries. ${ }^{32} \mathrm{He}$ observed the parallel between this story and Clement of Alexandria's claim that the heart of the Samothracian mysteries was a tale of two brothers who murdered a third, buried him, and then celebrated their crime. Clement identified the divine brothers as Kabeiroi, Kouretes or Korybantes; Ephoros, however, identified the Daktyloi with the Samothracian mysteries, and they were often equated to Kouretes. ${ }^{33}$ Rossignol suggested that Clement's account was simply his version of Kelmis' metamorphosis. Clement's polemical goals precluded recognizing a role for iron's invention in the mysteries, as this would associate the rites with a positive cultural advancement. In Stromateis (I, 16, 132), for example, Clement was eager to demonstrate that the Daktyloi who invented iron were Cypriote rather than Greek, in order to prevent the Greeks from taking pride in their achievement. Rossignol proposed, however, that the mysteries indeed celebrated the invention of iron, as the Eleusinian mysteries celebrated the origins of agriculture - and the Daktyloi, as smiths and goetes, were its priests. The two greatest mysteries of the ancient world thus memorialized the cultural evolution of human society.

13 A model of technological mysteries appealed to the age in which this hypothesis emerged. It drew on the evolutionary anthropological models that came from colonial encounters with primitive people, whose lack of metallurgy made them, in the eyes of their European investigators, modern analogs of prehistoric man. The model responded as well to the industrial revolution that had inspired a resurgence of scholarly interest in the guilds of medieval Europe, and the traditional beliefs of miners. ${ }^{34}$ These medieval rites and European traditions became the de facto model for the daimones and the mysteries, although the comparison was not made explicit, nor the differences between them explored. Roussel, in 1905, placed Rossignol's observations in an Indo-European context, citing a range of myths in which metals are generated from the body of a slain god. Gernet, in 1932, tied the origin of the rites to professional groups of itinerant smiths, for whom the island was a place of gathering and initiation into the secrets of their craft in the earliest phases of the iron age. ${ }^{35}$

\section{Metals and ritual power. a Pythagorean perspective}

The context of this Pherekydes citation suggests an alternative route to the combination of goeteia and metal, specific to the type of the Presocratic philosopher whose powers are evoked in the Argonaut's performance, and whose preference for pattern structures the fragment. Kingsley and others have noted that the goes' ritual powers derive from his understanding of cosmic structures. ${ }^{36}$ While Kelmis embodies telluric iron, his two brothers, Akmon and Damnameneus, refer more naturally to iron in the sky. Akmon, or "anvil," was also the name of Ouranos or Ouranos' father. ${ }^{37}$ Greek and Biblical authors from the $8^{\text {th }}$ to the $5^{\text {th }}$ centuries B.C.E. describe the sky in metallic 
terms, made either of iron or bronze ${ }^{38}$ Hesiod describes the distance between heaven and earth in terms of the time it would take an anvil to fall from one to the other (Theogony, 722-724); Homer recounts how Zeus hung Hera in the aether by fastening anvils to her ankles (Il. XV, 18-21). Eustathios refers to these bonds as mudroi, glowing masses of metal, and notes that Zeus cast them down to Troy after Hera's release. The image suggests a meteor's fall, and can be seen as well in the name 'Mudros' for the bay of Lemnos where Hephaistos landed after his expulsion from heaven ${ }^{39}$ Damnameneus offers similar combinations of smithing imagery and celestial locations. He is the only Daktyl whose personal name appears in the Papyri Graecae Magicae, where several citations identify him with Helios. ${ }^{40} \mathrm{His}$ connection with iron is less direct than either of his brothers; scholarly arguments have sought an etymological connection between his

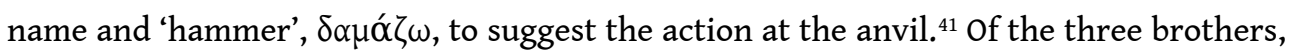
he shares more of Akmon's celestial location than Kelmis' metallic imagery.

The Pythagorean akousmata reflect a sensitivity to this combination of celestial location and metallic meanings, and connect it with the music that is the daimones' most famous characteristic. The Argonaut's dance in arms in attendance on the mother is a direct reflection of the armed dance that Strabo identifies as the essence of the Idaian Daktyloi, and the basis for their equation to the Kouretes, Korybantes, Kabeiroi and Telchines $(\mathrm{X}, 3,22)$.The aitia for the performance is the birth of Zeus on Crete, where fully grown, armed warriors sprang from the ground to protect the newborn by dancing about him, clashing their bronze swords and shields together. Of these daimonic attendants, it is the Daktyloi who set the rhythms of the dance in order, and gave it a name. They also invented epoidai, magical songs of supernatural effectiveness. ${ }^{42}$ Burkert has noted that the Daktyloi are the natural mythological expression of the Pythagorean perspective on magical songs, which triangulate between metal, daimones, and the pattern of the celestial spheres. ${ }^{43}$ These perspectives are transmitted in the akousmata, gnomic sayings that were both vehicles of instruction and enigmatic tokens. Many of them consist of a question and answer, and the term akousmata may be translated as "oral instructions." Thom notes that they were also, however, known as symbola or secret codes, and their secrecy inspired exegeses in the form of commentaries by Anaximander of Miletos, Philochorus and Androkydes. ${ }^{44}$ They exemplify the combination of secrecy and communication that characterizes the mysteries, whose vocabulary in turn is used to describe philosophical education. ${ }^{45}$

Akousmata are either definitional or prescriptive in form; the definitional akousmata are the minority of the extant corpus, and offer a quasi-scientific world view. ${ }^{46}$ It is among these that the observations on the relationship between daimones, music, metal and the celestial regions are found. One akousma states that the ring of bronze when it is struck is the voice of a daimon entrapped in it. ${ }^{47}$ Burkert compares this with the tradition that Pythagoras discovered the harmonics of the cosmos when he was passing by a smithy, and realized that the sounds of the hammers' blows reproduced the musical ratios of the fourth, fifth, and octave, e.g. 4:3, 3:2, and 2:1. ${ }^{48}$ Pythagoras then hung weights corresponding to these hammers from long strings and found that when he plucked them, the same intervals were produced. These celestial harmonies inspired Pythagoras' statement that the nine Muses were the sounds made by the seven planets, the sphere of the fixed stars, and the antichthon or counter-earth. Pythagoras was able to hear these harmonies because of the purity of his soul; he used them for the benefit of his friends, whom he calmed and purified by means of the songs. ${ }^{49}$ Iamblichus notes 
that Pythagoras restricted the term "music" to only these songs that purify, and speculates that the word epode or enchantment referred originally to this use (VP, 25). The catharsis this music provided was a key step in the process of philosophical instruction, and offers a direct path between daimones in metal, music, and the celestial spheres. ${ }^{50}$

The mechanisms of these epoidai are echoed in the Pythagorean perspective on the Ephesian letters, preserved in Clement of Alexandria's brief citation of Androkydes the Pythagorean. Androkydes was one of several authors who wrote texts on the akousmata; he represents the only extant Greek discussion of the meaning and origin, rather than simply the effectiveness, of these magical formulae. Ephesian letters were strings of names recited in time of need or engraved in amulets. They could ensure success or ward off danger; spoken aloud, they could protect a newly married couple; inscribed as amulets, they granted success to athletes. They were among the most common of the ancient magical formulae, and immensely popular..$^{51}$ Appearing as early as the $5^{\text {th }}$ century B.C.E., they represent the earliest manifestations of mystical terms, voces mysticae, which become widespread from the $1^{\text {st }}$ century C.E. onwards..$^{52}$ They represent one of many technologies of secrecy which fill the Papyri Graecae Magicae; others include lists of vowels, nonsense or foreign words, and unidentified symbols. Androkydes identifies the letters as Askion, Kataskion, Lix, Tetrax, Damnameneus, and Aisia, and their meanings, respectively, as darkness, light, the earth, the year, the sun, and the voice of truth. He concludes that the symbols thus show thow divine things are ordered, the shadow to the light, and the sun to the year, and the earth to all forms of nature." 53

Androkydes' list concurs with the Ephesian Letters as they appear in Hesychius, the Papyri Graecae Magicae, and magical tablets..$^{54}$ Damnameneus' name provides a direct connection to the Idaian Daktyloi, and Clement observes that the Daktyloi invented both these formulae and musical rhythms, an observation for which Androkydes seems a likely source (Strom. I, 15, 132). Plutarch affirms the association of the Daktyloi with celestial phenomena and magical power, noting that the Idaian Daktyloi and the Korybantes are daimones who live in the moon, and that superstitious people would recite their names as an aid in times of trouble (De facie in orbe lunae, 30; De profectibus in virtute,15). The combination of secret names and cosmic and celestial bodies corresponds to the use in the magical papyri of charakteres, visual symbols, and vowel sequences, as codified references to planetary phenomena, angels and sounds. ${ }^{55}$ Androkydes' observations are thus consistent with magical practices that used code names to elevate secrecy, and appealed to celestial phenomena. His statement provides an earlier date for these practices than the bulk of the testimonia, affirming the observations of Faraone and others that Hellenistic magical materials often reflect much older practices.

\section{Daktyloi in the cave of Zeus: Pythagoras' initiation}

Porphyry's account of Pythagoras' initiation into the mysteries of Cretan Zeus offers a Neopythagorean perspective on the Daktyloi's goeteia. The mystery initiations of $6^{\text {th }}$ century B.C.E. sages was a familiar Hellenistic trope; Iamblichus and Diogenes Laertius affirm Pythagoras' initiation, and many authors report his journey to the island. ${ }^{56}$ Porphyry alone includes a Daktyl and a keraunia lithos. His interest in caves as cult sites, reflected in his study on the cave of the nymphs, was greater than that of Pythagoras' 
other biographers. His description is consistent with Daktylic type, Cretan cult, and regional history, and suggests resonances with Androkydes' observations of seven centuries earlier. Both Porphyry and Androkydes demonstrate that the Pythagorean perspective on the Daktyloi, while unique in its expression, reflects neither their own invention, nor the rituals of long-missing smiths. The consistency with cultural norms indexes the saturation of this type into its cultural setting, and the inadvisability of reading it as a separate entity.

Porphyry writes that Pythagoras, enroute to Italy, was initiated into the mysteries of Zeus at the Idaian Cave on Crete. He descended into Zeus' cave, where a mystagogue named Morgos, one of the Idaian Daktyloi, purified him with the help of a keraunia lithos. At daybreak, Morgos instructed his initiate to stretch out on the ground, face down, by the sea; at night, he crowned him with the wool of a black sheep on the banks of a river. Pythagoras spent thrice nine days underground in the cave of Ida, covered with black wool. While there he offered a funerary sacrifice for Zeus; he saw the throne that is decorated for Zeus every year, and wrote on the tomb an epigram, 'Pythagoras to Zeus', which begins: Zas lies here dead, whom they call Zeus (VP, 17).

The account conforms with Cretan traditions and Hellenistic interests. The Zeus capable of birth and death is a well known Cretan tradition; katabaseis were an especially popular element in mysteries of the Hellenistic period; and the face-down position, the black wool, the descent into the cave, and the number imagery are consistent with rituals focused on death and rebirth. ${ }^{57}$ Morgos' name is otherwise unconnected with the Idaian Daktyloi, but Faure notes that the elements of his name appear in southern Italian place names, making him an appropriate figure for Pythagoras to encounter on his way to Italy. ${ }^{58}$ Diogenes Laertius suggests that Pythagoras and Epimenides descended into the cave together, connecting Pythagoras' initiation with the more abundant evidence for Epimenides' mystic experiences in Zeus' cave. ${ }^{59}$ In identifying the mystagogue as a Daktyl, however, Porphyry makes a significant departure from tradition. The majority of the ancient sources for Zeus' birth, and the Cretan rites that celebrate it, describe his attendants as Kouretes rather than Daktyloi. ${ }^{60}$ Porphyry does so himself, in De antro nympharum, and Iamblichus described Pythagoras acting, after his initiation, in terms appropriate for the prophetic Kouretes. ${ }^{61}$ The Daktyloi are associated with the rites either through their assimilation to Kouretes, their kinship with local divinities or Zeus' nurses, or through folk etymologies that derive their name from the handprint of Rhea as she gave birth, or the dust as it flowed through her attendant's fingers. ${ }^{62}$ Their adjective "Idaian" could refer either to Cretan or Phrygian Mount Ida; Zeus' birth is more generally located in Crete, but the mother on whom the daimones attend is deeply rooted in Asiatic traditions. A katabasis ritual of the $3^{\text {rd }}$ to $4^{\text {th }}$ centuries C.E. may refer to the cave of the Daktyloi; Jordan, however, has noted that 'of the Daktyloi' is a marginal note, and likely to indicate simply the rhythm in which the charm was to be performed. ${ }^{63}$

Porphyry's Daktyl is thus a matter of choice rather than convention. Marinatos, Faure, Hiller and Hurst have sought the reason for this choice in a literal connection between the daimones of the cave and the metallurgical history of Crete, appealing to Cypriote sites for comparanda. ${ }^{64}$ In Late Bronze Age Kition, metals were manufactured in the open courtyard of the temple; a god mounted on an ingot-shaped stand, found at Enkomi, has been cited as corroboration; other sites combining metal production and sacred activities include Athienou, Kalopsidha, and Tamassos. ${ }^{65}$ Marinatos suggests the 
Cretan data reflect the existence of a class of smith-shamans; Hiller and Hurst, that they suggest metallurgical production carried out under the guidance of Zeus' priests as part of an initiation ritual. Faure suggests that the importance of metals in the Cretan economy would lead naturally to their incorporation into the island's mysteries; this is an elaboration of observations first published by Engels in 1841, that myths about daimones who make metal, e.g. Daktyloi, Telchines and Kabeiroi, place them in regions that were historically rich in ores. Morris has expressed caution about sacred smiths, but has noted the role of Phoenician contact in shaping these coincidences; the Kabeiroi appear often at sites located on the metals trading route, visited by Phoenicians. ${ }^{66}$ The etymological derivation of their name from Semitic $k b r$, first proposed by Scaliger in the $15^{\text {th }}$ century, supports a model of myth, ritual and trade moving in Phoenician ships, whose metal-hungry skippers favored the richest metallurgical sites. ${ }^{67}$

These all attempt to link a metallurgical reality with metallurgical gods, building implicitly on models of ritual and economy first developed by Robertson Smith and Durkheim. These have not lacked ethnographic substantiation, which have demonstrated the variety of forms the relationship may take, responding to differences in social and political structure, economic complexity, local tradition and cultural norms. These recommend close consideration of the context of examples, and a use of the models as heuristic tools rather than prescriptive definitions. Marinatos' proposal rests on a view of myth as prehistory, and the shaman's magic as a lack of technological understanding. pace the fantasy of Hephaistos' education in Thetis' grottoes, caves are poor locations for metal production, as the lack of ventilation could be inconvenient if not fatal; the absence of tools, manufacturing debris, partially or imperfectly cast materials from the caves further advise against it. Cyprus, in addition, had a uniquely dominant role for metallurgical production in the economic structure. Knapp has argued that the Cypriote materials represent elite attempts to control this economically central industry through manipulation of sacred symbols. ${ }^{68}$ Such ritual expressions are effective precisely for their high visibility. The long pilgrimage to the cave, and the secrecy or at least discretion that is part of the initiatory and katabasis rituals, suggest that if these Idaian Daktyloi were relevant to the local metal industry, they served a ritual purpose substantially different from Cypriote examples.

\section{Stones from heaven and rituals for Zeus}

Porphyry's second hapax, the keraunia lithos, offers a route of investigation specific to the Pythagorean perspective on the role of the Daktyloi in Zeus' rites. Pliny defined Daktyloi as gray, thumb-shaped Cretan stones (HN XXXVII, 170); Faure suggests that the keraunia lithos of this passage could be understood as a Daktyl by this definition. ${ }^{69}$ Pliny's discussion of keraunia lithoi, however, offers more intricate connections with the Idaian Daktyloi and with Pythagorean concerns. Pliny divides these stones into two types: meteors that fall from heaven, and a rarer sort formed where lightning strikes the earth (HN XXXVII, 135)..$^{70}$ The first are the more familiar in metallurgical history, ritual practice, and Cretan, Greek and Levantine traditions. They offer potential, if hypothetical, connections with the Daktyloi in their celestial locations and their metallurgical inventions. Historical models and ancient names for iron emphasize the importance of meteoric sources in the earliest stages of iron's use. Earlier models of 
metallurgical history suggest that meteoric iron was the first to be used for ornaments and tools. Texts from Mari, Egypt, and Hittite archives refer to iron as a black stone from heaven, and reflect elite, votive and ritual uses that correspond to archaeological finds in both Greek and Levantine contexts, in which iron is limited to ritual and burial use. ${ }^{71}$ If the first iron in human use were meteoric, the meteor would share the Daktyloi's connection with the discovery of iron. Neither this historical model, however, nor the ancient terminology for iron, accurately reflect the archaeological evidence for the onset of the iron age. More recent analyses of archaeological materials note that while meteoric iron was used from an early time, the first iron artifacts are as likely to be telluric as meteoric. ${ }^{72}$ Sherratt proposes that these celestial names placed iron firmly within the province of the theocratic ruler and elites, who were thus able to claim a monopoly on its use and circulation..$^{73}$ The relationship between the Daktyloi and the meteors is less direct than these oriental etymologies; it may inform, however, the mythic and ritual contexts of Zeus' birth, and ritual celebration of Herakles Daktylos.

Greek tradition links stones that drop from the sky to the myth of Zeus' birth. These traditions offer light on the semantics of the keraunia lithos in the Cretan mysteries. Stones from heaven share aniconic form,primitivism,descent from heaven, prophetic powers and animation with agrioi lithoi,baityloi and xoana. ${ }^{74}$ Pausanias reported that the baityl at Delphi was considered the stone Kronos swallowed in Zeus' stead (X, 24, 6); the proverb "you ate a baityl" compares the gluttony of mortal diners to Kronos' cannibalism, and late antique authors define a baityl as the stone Kronos swallowed in the place of his son..$^{75}$ Pausanias describes an agrios lithos, a unworked stone, of Zeus Kappotas that purified Orestes of his madness. (III, 22, 1) ${ }^{76}$ Philo of Byblos describes the baitylos as a lithos empsychos, invented by Ouranos, and one of the four sons of Ouranos was named Baitylos. These are characterized by powers of prophecy and of animation. Damascius writes of them as fallen meteors that could move, speak and tell the future. ${ }^{77}$ The best visual evidence for the use of the baityl in cult comes from Phoenician coins from Sidon, Byblos, Tyre and Cyprus; the derivation of the term from Hebrew beth-el, house of god, is at this point nearly certain. ${ }^{78}$

Crete had a long tradition of aniconic lithic statues and demonstrates, at Kommos, a particular receptivity to Levantine customs of baityloi. Archaeological remains, depictions of cult scenes on sealing rings, and clay models reflect the existence of pillar cults in the Middle Minoan and Late Minoan palaces. Sacred caves in these periods yield offerings ranging from terracotta figurines to gold double axes, given to stalagmites and elaborate rock formations. Stalagtites have also been found in ritual settings outside of caves, and Minoan seals show them placed on altars; figures approaching these altars are depicted in attitudes of ecstasy, suggesting the presence of a divinity in the stone..$^{79}$ The Idaian cave includes rock formations that received cultic celebration of this sort..$^{80}$ The cave was the richest of Crete, with a particular abundance of orientalia starting in the $9^{\text {th }}$ and $8^{\text {th }}$ centuries B.C.E. Pilgrims to the cave may have begun their trek from Kommos, a coastal site from which Shaw has suggested travelers would begin their pilgrimage to the sanctuary. A shrine with distinctly Phoenician architecture has been excavated at the site, in which three baityloi received cultic offerings in the late $9^{\text {th }}$ and $8^{\text {th }}$ centuries B.C.E. ${ }^{81}$

The keraunia lithos thus lies well within the familiar range of Greek ritual, Zeus' cults, Cretan tradition, the history of the Idaian cave and Phoenician rites as practiced on the 
island. The need for purification was equally typical for the situation. Catharsis was essential in initiations, mysteries, and encounters with the dead, among the key skills of the goetes, and within the parameters of the Pythagorean sage, who purified his students so they could advance in understanding. The only parallel for using meteoric stones as instruments of purification, however, is the lithos agrios of Zeus Kappotas, mentioned above. Pliny's second type of keraunia lithos suggests both material and a model for cathartic ritual more within the Greek norm (HN XXXVII, 135).Pliny notes that the magi sought these stones with particular eagerness, and that they were found where lightning had struck the earth. Authors from Homer onward report that the strike of lightning was accompanied by the smell of sulphur. ${ }^{82}$ Sulphur was a common additive in purification by fumigation, providing an acrid smell that emphasized the change wrought by the performance of the ritual. ${ }^{83}$ Ancient etymological speculation derived the word sulphur, theion, from theos, and suggested that its celestial origin in Zeus' lightning was the source of its purifying power. ${ }^{84}$ Lightning provides an image as well of purifying fire, which may extend to the strike of lightning that creates this stone..$^{85}$

The ambiguity of the keraunia lithos thus allows simultaneous reference to Greek, Cretan and Phoenician ritual, and to the form of purification most connected with the celestial spheres. The image also offers intricate connections with the myths and rituals of the Daktyloi, whose inclusion in this context is Porphyry's second departure from the norm. Seductively literal relationships may be argued between the Daktyloi and a rock of iron, sent from heaven. The celestial correspondences of the Idaian Daktyloi, discussed above in connection with Androkydes, suggest that the meteor's celestial origin is well within the Daktyloi's semantic range. Anaxagoras, the Presocratic philosopher of the $5^{\text {th }}$ century B.C.E., was said to have predicted the meteor of Aigospotamoi, based on his interest in parallel materials in heavenly and earthly bodies. ${ }^{86}$ The Daktyloi could provide a mythological counterpart for his theories, as well as for Levantine etymologies that emphasize iron in the sky. The Daktyloi also have numerous connections, in their mythological record, with celebration of divinities in archaic or aniconic form. The xoanon the Argonauts construct for the Great Mother is one example; it assumes lithic form in the celebrations of Cybele, on whom the Daktyloi often attend. A fragment of Kallimachos connects Kelmis or a variant of his name, Skelmis, with the production of the earliest aniconic statues. Wilamowitz has argued, in connection with this fragment, that etymological parallels between Kelmis' name and a Thracian term for carving knife also reflect the association of the Daktyloi with statues at the point at which they moved from unmodified, naturally occurring forms to crafted works. ${ }^{87}$ These are scattered observations; Herakles Daktylos provides a single figure in whom traditions of animated cult images, ritual purification, Levantine antecedents, and the authority of the goes combine.

\section{Herakles Daktylos and magical stones}

Herakles the Daktyl is an attendant on the great mother, a magician, and a healer; Cicero notes that he was celebrated with offerings for the dead. (De natura deorum III, $16,42)$ Pausanias, citing sources as early as the Orphic Onomakritos of the $6^{\text {th }}$ century B.C.E., reports his celebration in central Greece, Ionia, and the Peloponnesos, in the form of a diminutive statue attending on the Great mother. His image opened and 
closed the doors of her temple in Mykalessos every day. ${ }^{88}$ Pausanias writes that the Peloponnesian Herakles came from Crete, and that with him came four brothers whose names reflect medical power: Paionaios, named for the physician of the gods; Epimedes, "skilled in herbs;" Iasios, "the healer," and Akesidas, "he who mends". ${ }^{89}$ Diodorus Siculus reports that the historical figure by this name was so skilled in goeteia, epoidai and teletai that the women of the region made amulets in his honor even in Diodorus' day $(\mathrm{V}, 64)$. Pausanias describes another Herakles Daktylos, celebrated in Hyettos in Boiotia, as the same one celebrated in Erythrae in Ionia and Tyre (IX, 27, 8). The sick would come to his temple to be cured; Wilamowitz proposed that this Herakles had assumed the place of an old healing hero, possibly Trophonios or Amphiaraos. ${ }^{90}$ Pausanias describes the image of the god as "not carefully carved, but of unwrought stone after the ancient fashion." (IX, 24, 3) The region of Hyettos was particularly rich in magnetite, known in antiquity as the Herakleian stone, whose medicinal uses include the treatment of women's ailments and colic. Etienne and Knoepfler suggest that the stone that represented the god could have been a large piece of this local stone, a cult statue offering healing powers analogous to the amulets the Peloponnesian women made. ${ }^{91}$

The Tyrian Herakles to whom Pausanias equates this Boiotian was represented in a cult statue of even more miraculous power (VII, 5, 5-9). The statue was very old, and made in the Egyptian manner. Leaving its temple in Tyre one day, it placed itself on a raft and travelled up the coast to cape Messate, equidistance between Erythrae and the island of Chios. The cities quarreled over the rights to bring it to shore; the answer came from a blind Erythrean fisherman named Phormion. He had a vision that the women of Erythrea should cut their hair, which the men would form into a rope and use to drag the raft to shore. The citizen women refused, but all of the Thracian women in the city, both slave and free, complied. The Thracian women were honored in the cult with exclusive rights to enter the Herakleion, and the rope of their hair held pride of place among the temple offerings even in Pausanias' time. The fisherman, for his service to the god, was cured of his blindness.

There is little evidence of Phoenician activity in Erythrae to corroborate this story, and none early enough to match the $9^{\text {th }}$ to $7^{\text {th }}$ century B.C.E. dates that Pausanias' story implies..$^{92}$ As an aitiological tale, however, the story connects Herakles Daktylos with a lithic form whose Phoenician resonances and healing powers recall Pythagoras' initiation on Ida, and whose animation, prophecy, and antiquity correspond to the historical type of the meteoric cult image. By describing the statue as Egyptian, Pausanias suggests a Bes figure, whose lion's skin and warrior attitude approximate Herakles. Tzavellas-Bonnet et al. have studied the translation of Bes into Melqart and Herakles on Cyprus. ${ }^{93}$ Herakles Daktylos offered an iconographic and functional type appropriate for the translation, as he maintains the healing and apotropaic force of Bes through his status as a goes, master of amulets, and special protector of women. The behavior of the statue emphasizes the Phoenician type of stones from heaven capable of animation and prophecy. The vision sent to the blind man demonstrates the prophetic powers traditionally associated with the baityloi, and with the cave of Zeus and the Kouretes; the restoration of his sight suggests the healing that characterized this Herakles and his medical brothers. The rope of hair is a familiar element in Phoenician religion, and a striking parallel with the women who pulled Cybele's meteor to shore in Rome. ${ }^{94}$ That only the Thracian women responded to the statue's demands 
may reflect the traditional Phoenician origins of the Herakles cult on Thasos; they may have recognized, in this migrating stone, a familiar divine Phoenician type. ${ }^{95}$ Pausanias' statement that the Erythrean, Tyrian and Boiotian Herakles Daktylos were the same brings this statue into the semantic realm of the Hyettan cult statue and its healing powers. The healing powers of Herakles' stone offer the closest functional parallel to the purification of Porphyry's keraunia lithos, as catharsis was key to both healing and initiation.

Herakles Daktylos thus provides ancient evidence of the semiotic and ritual range of a keraunia lithos informing the celebrations of a Daktyl. Porphyry's combination of the two is not merely his authorial invention, but manifests patterns of association that go beyond his immediate story. The Daktyloi and this stone evoke a complex range of ritual powers including prophecy, animation, and healing, drawing on Phoenician, Cretan and Greek types. They locate the imagery in the historical circumstances of Crete, where Daktyloi were at home and stones were frequent objects of worship. Both Porphyry and Androkydes, in their observations on the Idaian Daktyloi, suggest less a Pythagorean innovation in the employment of the daimones, than how thoroughly integrated they were into the landscape of Greek ritual practice. Both also suggest that from the Pythagorean perspective, the Daktyloi's most semiotically useful iron was celestial rather than telluric. The ritual usefulness of the Idaian Daktyloi is less to be discovered in the search for missing smiths, than in their integration into the intellectual systems of those who wrote of them.

\section{Conclusion: Attribution, evolution, and an anthropology of technology}

Lemonnier advises that technological sema are vital less for their snapshot of technological history than for their placement of that technology within other cultural systems of meaning. ${ }^{96}$ Pherekydes' statements on the Idaian Daktyloi invite consideration of these daimones against the intellectual models of the Pythagorean tradition. The exercise suggests that the Daktyloi offered cosmological and professional models for the Presocratic sages, and recommends the authorship of Pherekydes of Syros above his Athenian counterpart for this problematic fragment. It offers as well a new perspective on the larger puzzle of the magician smith within the Greek tradition. Investigations to date have proceeded from an a priori assumption of the relevance of the Daktyloi for ancient smiths; with this assumption has come an unexamined application of evolutionary and survivalistic models that obscure the sophistication of the daimones as an intellectual type. Consideration of the use of the image, rather than its real-world referent, reveals that the Daktyloi were a far more flexible image than models of compensatory magic, or survival of superstitions, have suggested. They, their metal, and their ritual power are intricately connected within magical practice, mystery cult, cosmological structures, mythic tradition, and Cretan history. They emerge less as fragmented oddities than as cogent images functioning in numerous cultural and semiotic systems. How, or if, ancient smiths found use for the Daktyloi, we may never know. Their words enter the written record but little, and no archaeological evidence suggests dedications or performances of the smiths in the daimones' honor. The demonstrable vitality of the Daktyloi within the Pythagorean tradition, however, counters the assumption that absence from the canon is a sign of insignificance, and 
suggests that unexamined investigative models may limit our understanding as much as the fragmentary quality of the data itself.

\section{NOTES}

1. B. PFAFFENBERGER, “Social Anthropology of Technology," Annual Review of Anthropology 21 (1992), p. 491-516; D. KILLICK, Technology in its social setting: The ironworkers of Kasungu, Malawi, 1860-1990, Ph.D. dissertation, Yale University, 1990; J.S. LANSING, Priests and Programmers: Technologies of Power in the Engineered Landscape of Bali, Princeton, 1991.

2. C.R. PHILLIPS, "Seek and Go Hide," Helios 21:2 (1994), p. 107-114; T.A. WERTIME, "The Furnace vs. the Goat: The Pyrotechnologic Industries and Mediterranean Deforestation in Antiquity," JFA 10 (1983), p. 445-452; P. BUDD, T. TAYLOR, "The faerie smith meets the bronze industry," World Archaeology 27:1 (1995), p. 133-143; M. DELCOURT, Héphaistos ou la légende du magicien, Paris, 1957; R.J. FORBES, Studies in Ancient Technology, $2^{\text {nd }}$ ed., vol. VIII (1971), p. 71-99.

3. B. HEMBERG, "Die Idaiischen Daktylen," Eranos 50 (1952), p. 41-59 remains the standard collection of the ancient sources.

4. A. HENRICHS, "Three Approaches to Greek Mythography," in J. BREMMER (ed.), Interpretations of Greek Mythology, London, 1987, p. 242-277; J.Z. SMITH, "Towards Interpreting Demonic Powers in Hellenistic and Roman Antiquity," ANRW II.16.1 (1978), p. 425-439.

5. For European dwarves, see J. GRIMM,Deutsche Mythologie, vol. 3, Göttingen, 1854, p. 415-440; U. VON WILAMOWITZ-MOELLENDORFF, "Hephaistos," NAWG (1895), p. 241-44; C. BLINKENBERG, "Rhodische Urvölker," Hermes 50 (1915), p. 285; B. HEMBERG, Die Kabiren, Uppsala, 1950, p. 46; for shamans, see DELCOURT, o.c. (n. 2), p. 133; E.R. DODDS, The Greeks and the Irrational, Berkeley, 1951; M. ELIADE, The Forge and the Crucible, tr. S. Corrin, Chicago, 1962; W. BURKERT, "ГОН $\Sigma$ : Zum griechischen "Schamanismus," RhM 105 (1962), p. 36-55, contraJ. BREMMER, "The Birth of the Term 'Magic'," ZPE 126 (1999), p. 1-12.

6. P. KINGSLEY, Ancient Philosophy, Mystery and Magic, Oxford, 1995, p. 8 cites C. MILlERD, On the Interpretation of Empedocles, Chicago, 1908, 1-2, 79-81; G.E.R. LLOYD, Polarity and Analogy: Two Types of Argumentation in early Greek Thought, Cambridge, 1966.

7. W. BURKERT, Lore and Science in Ancient Pythagoreanism, Cambridge, 1972; G.E.R. LLOYD,Magic, Reason and Experience: Studies in the Origins and Development of Greek Science, Cambridge, 1979; KINGSLEY,o.c. (n. 6); M. DICKIE,Magic and Magicians in the Greco-Roman World, London, 2001; C.A. FARAONE, "Binding and Burying the Forces of Evil: The Defensive Use of Voodoo Dolls in Ancient Greece," CA 10 (1991), p. 165-205; PHILLIPS, l.c. (n. 2), p. 110.

8. F. GRAF, "Myth and Technology in Antiquity," in R. BUXTON (ed.), From Myth to Reason? Studies in the Development of Greek Thought, Oxford, 1999, p. 317-328.

9. The earliest evidence for the daimones is approximately 300 years after the onset of the iron age as set by A. SNODGRASS, "Iron and Early Metallurgy in the Mediterranean," in T.A. WERTIME, J.D. MUHLY (eds.), The Coming of the Age of Iron, New Haven, 1980, p. 335-374. J.D. MUHLY, "The Bronze Age Setting," ibid. p. 25-68, argues that the comparison of Polyphemos' blinding to a magical act in Homer Odyssey IX, 389-394 suggests its relative novelty; the precision of the description, however, may also suggest its familiarity. 
10. P. LEMONNIER, "Introduction," in id. (ed.), Technological Choices: Transformation in material cultures since the Neolithic, London, 1993, p. 1-35.

11. PFAFFENBERGER,l.c. (n. 1)

12. n.b. the variations between the scholia as published by F. JACOBY in FGH and C. WENDEL,Scholia in Apollonium Rhodium Vetera, Berlin, 1958, p.101. Wendel identifies their number as five only, rather than six and five, replacing $\check{\varepsilon} \xi \kappa \alpha i ́$ with $\dot{\varepsilon} \kappa \alpha \tau \varepsilon$ couc; Wendel identifies Pherekydes' numbers as ten and twelve for right and left, instead of twenty and thirty-two, respectively. Wendel also positions the sentence "they were named for Mother Ida" last in the fragment, and

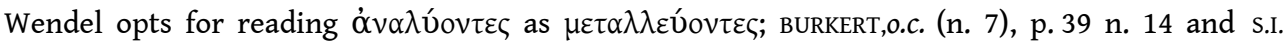
JOHNSTON, Restless Dead: Encounters between the Living and the Dead in Ancient Greece, Berkeley,1999, p. 105 n. 54 reject the emendation.

13. F. ЈАсову, “The First Athenian Prose Writer," Mnemosyne, $3^{\text {rd }}$ series, 13 (1947), p. 13-64.

14. JACOBY, l.c. (n. 13); H.S. SCHIBLI, Pherekydes of Syros, Oxford, 1990, p. 80; M.L. WEST,Early Greek Philosophy and the Orient, Oxford, 1971, p. 27; A.W. BULLOCH, "Hellenistic Poetry," in P.E. EASTERLING, B.M.W. KNOX (eds.), Cambridge History of Classical Literature I: Greek Literature (1985), p. 541-621.

15. U. VON WilamowitZ-MoellendorfF, "Pherekydes," in id., Kleine Schriften, vol. 2, Glaube und Sage, Berlin, 1926 [1971], p. 127-156.

16. SCHIBLI,o.c. (n. 14), p. 13.

17. SCHIBLI,o.c. (n. 14), p. 80; 7 b8D-K.

18. Hellanikos, 4 F 89 (ed. JACOBY); Stesimbrotos, 107 F 12 (ed. JACOBY); Pliny, Historia Naturalis XXXVII, 170; Pollux, Onomasticon II, 156; Diomedes Grammaticus, II, 57, 13.

19. LLOYD,o.c. (n. 6), p. 49; Aristotle, Metaphysica, 986a 22 f.

20. The complete list of opposites is limit/unlimited; odd/even; one/plurality; right/left; male/ female; resting/moving; straight/crooked; light/darkness; good/bad; square/oblong: see BURKERT,o.c. (n. 7), p. 51.

21. Arist., Ethica Nicomachea, 1096b 5; 1106b 28f; Metaph. 1093b 1f; b 27; Physica 201b $25=$ Metaph., 1066a 14. Other authors include Speusippus, cited in Arist., Metaph., 1096b 6; BURKERT, o.c. (n. 7) 1972, p. 51-52 notes that Hermodorus' On the Good, cited in Simplicius, Physica, 247, 30, appeals to the same pattern, and notes the use of the Aristotelian conception of the sustoichia in Plutarch, De Iside et Osiride, 48 (370e); Porphyry, Vita Pythagorae, 38; Eudorus ap. Simpl. Phys., 181, 22ff; "Pythagoras" in Varro, Delingua latina V, 11; Ps-Archytas, p. 19, 5-13 Thesleff; "Eurysus" in Stobaeus, I, 6, 19; Philo, Quaestionesin Exodum II, 33; cf. also Timaeus, Locr. I. Aristotle considers it possible that Alcmaeon already knew the table, but it could also be older than him. See also WEST, o.c. (n. 14), p. 25; G.S. KIRK, The Presocratic philosophers, Cambridge, 1957, p. 50-51; LLOYD,o.c. (n. 6), 59, 65 notes the appearance of the sustoichia in the akousmata.

22. SCHIBLI, o.c. (n. 14), p. 14-103.

23. JACOBY, o.c. (n. 13), p. 62-63.

24. Arist., Metaph. N4, 1091b 8; Diogenes Laertius, I, 116; Cicero, De divinatione I, 50, 112; Flavius Josephus, Contra Apionem I, 14; Kendros Georgion, Compendium historiarum, P 9b.

25. F. GRAF, "Pythagoreanism," in S. HORNBLOWER, A. SPAWFORTH (eds.), The Oxford Classical Dictionary3, Oxford, 1999, p. 1283-1285; DICKIE, o.c. (n. 7), p. 203-204; J.C. тHOM, The Pythagorean Golden Verses, Leiden, 1995, p. 35-58; KINGSLEY,o.c. (n. 6).

26. JOHNSTON, o.c. (n. 12), p. 103-105; BURKERT, o.c. (n. 5); DICKIE, o.c. (n. 7), p. 13.

27. D.L., VIII, 59; Empedokles 31 B 111 D-K.

28. Diod. Sic., V, 55, 3; Porph., VP, 41; Diogenes Laertius, Vita Pythagorae, 1; W. FIEDLER, Antiker Wetterzauber, Stuttgart, 1931, p. 17-19.

29. A.A. DONOHUE, Xoana and the Origins of Greek Sculpture, Atlanta, 1988, p. 45-46.

30. In D.L., VIII, 59, for ex., Empedokles brags that he will teach his students to stop winds that destroy fields, make breezes to compensate, and make tree-nourishing streams pour forth. 
31. Zenobius, IV, 80; Sophokles, fr. 335 (ed. NAUCK ${ }^{2}$ ); $c f . R$. WALKER, Sophoklean Fragments, London, 1921, p. 32; Plut., Proverbia, 1254.

32. J. ROSSIGNoL, Les Métaux dans l'antiquité, origines religieuses de la métallurgie, Paris, 1863.

33. Clement of Alexandria, Protreptikos II, 15; Ephoros, 70 F 104 (ed. JACOBY); Strabo, X, 3, 22; VII, fr. 50; X, 3, 7; Pausanias, V, 7, 6; Scholia Aratus, 33; Diodorus Siculus, V, 65; PGM 985; Hippolytus, Refutatio Omnium Haeresium $\mathrm{V}, 7,3$.

34. A. DAUBRÉE, "La génération des minéraux métalliques dans la pratique des mineurs du Moyen Age d'après le Bergbüchlein," JS (1890), p. 379-392; 441-452; Р. SEBILLOT, Les travaux publics et les mines dans les traditions et les superstitions de tous les pays, Paris, 1894.

35. P. ROUSSEL, “KE $\Lambda \mathrm{MI} \Sigma$ 'EN $\Sigma I \Delta H P \Omega$," Revue de philologie de litterature et d'histoire, n. ser., 29 (1905), p. 292-295; L. GERNET, A. BOULANGER, Le génie grec dans la religion, Paris, 1932.

36. KINGSLEY,o.c. (n. 6), p. 229 n. 44.

37. Hesychius s.v. ö́ $\mu \omega v$ (ed. scHMidT I [1965], p. 100); cf. HEMBERG,o.c. (n. 5), p. 293 and l.c. (n. 3), 51.

38. Homer, Iliad V, 504; XVII, 425; XVIII, 47, Od. III, 2; VIII, 274; XV, 329; Pindar, Pythian X, 27; Nemean VI, 3; Herodotus, I, 68; Exodus 39, 3; Numbers 17, 3; Isaiah 40, 19; Jeremiah 10, 9; Job 37, 18. For discussion, see M.L. WEST, The East Face of Helikon, Oxford, 1997, p. 139-144.

39. Eustathius, in Iliadem 1003, $13 \mathrm{ff} ;$ cf. Servius, adAeneidem I, 640.

40. C. BONNER, Studies in Magical Amulets, Ann Arbor, 1950, p. 201; M. HUVELIN, "Les tablettes magiques et le droit romain," Annales Internationales d'Histoire: Congrès de Paris $19001^{\text {re }}$ section, Paris, 1901, p. 15-81; Clement of Alexandria, Stromateis V, 56, 8; K. WESSELY, Ephesia Grammata aus Papyrusrollen, Inschriften, Gemmen, etc. Vienna, 1886; n. 54 infra.

41. HEMBERG,l.c. (n. 3), p. 50; Euripides, Alestis, 980; Cornutus, 19.

42. Clem. Al., Stromata V, 15, 132; Solinus, Collectanea rerum memorabilium sive polyhistor, 11, 4-6.

43. BURKERT,o.c. (n. 7), p. 377.

44. BURKERT, o.c. (n. 7), p.167-175, 191-192; THOM, o.c. (n. 25), p. 94-95; A. DELATTE,Études sur la littérature pythagoricienne, Paris, 1915; M.P. NILSSON,Geschichte der griechischen Religion, Munich, $1974^{3}$, p. 77-78.

45. F. GRAF,Magic in the Ancient World, Cambridge, 1997, p. 96-117.

46. тном,o.c. (n. 25), p. 101.

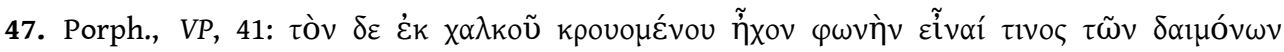

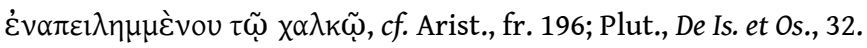

48. BURKERT, o.c. (n. 7), p. 375-377, citing Nicomachus Gerasenus, Harmonicum Enchiridium 6 p. 245 ff. = Iamblichus Vita Pythagorae, 26 (115 ff); see also Macrobius, Commentarii inSomnium Scipionis II, $1,9 \mathrm{ff}$.

49. Porph., VP 30-31, 45; Iamb., VP 15.

50. BURKERT,o.c. (n. 7), p. 376 cites, on musical catharsis, Iamb., VP, 163 f 229; VP, 64 f 110; Aristides Quintilianus, 2 p. 110 M., Scholia T. Iliad XXII, 391; Porph., VP, 30, 33-39. Cf. W.K.C. GUTHRIE, A History of Greek Philosophy: Volume 1, The earlier Presocratics and Pythagoreans, Cambridge, 1962, 295-301; P. BOYANCÉ,Le culte des Muses chez les philosophes grecs, Paris, 1972, p. 3-16, 349-351; H. THESLEFF, The Pythagorean Texts of the Hellenistic Period, Abo, 1965, p. 186 n. 22.

51. WESSELY,l.c. (n. 39); HUVELIN,l.c. (n. 39); c.c. Mccown, "The Ephesia Grammata in Popular Belief," TAPhA 54 (1923), p.128-140; R. котANSKY, "Incantations and Prayers for Salvation on Inscribed Greek Amulets," in C.A. FARAONE,D. OBBINK (eds.), Magica Hiera: Ancient Greek Magic and Religion, Oxford, 1991, p. 107-137; K. PREISENDANZ, "Ephesia Grammata," RAC vol. 5 (1965), col. 515-520.

52. D. JORDAN, "Ephesia Grammata at Himera," ZPE 130 (2000), p. 104-107 notes that lead tablets from Selinous, Phalasarna, and Lokroi Epizephyroi, together with a fragment of Anaxilas, PCG fr. 18, established a $4^{\text {th }}$ century date for the Ephesian Letters; the Himera tablet, however, dates to 
the fifth century B.C.E., and contains scribal errors suggesting that the tradition was old and widely disseminated even at that earlier date. See also J.G. GAGER,Curse Tablets and Binding Spells from the Ancient World, Oxford, 1992, p. 5-6; KOTANSKY, l.c. (n. 50), p. 127; H.D. BETZ, "Secrecy in the Greek Magical Papyri," in H.G. KIPPPENBERG, G.G. STROUMSA (eds.), Secrecy and Concealment: Studies in the History of Mediterranean and Near Eastern Religions, Leiden, 1995, p. 153-176.

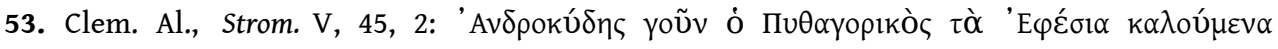

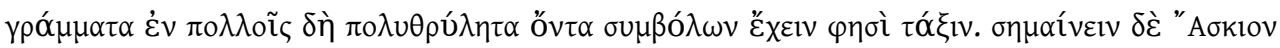

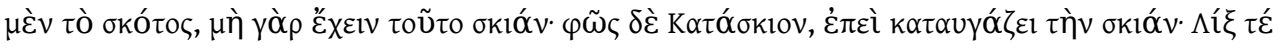

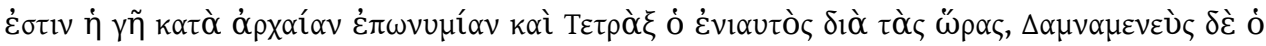

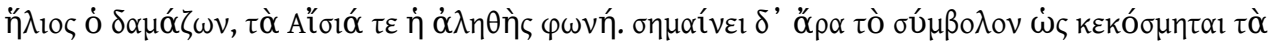

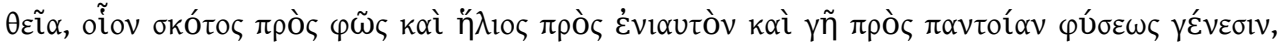
"Androkydes the Pythagorean, for example, of the so-called Ephesian letters says they are very famous and play a symbolic role; he says that Askion signifies darkness, for he has no shadow. And Kataskion is light, since it illuminates the shadow. Lix is the earth, after an ancient name, and Tetrax is the year, causing the seasons; Damnameneus, the sun, is the lord, and Aisia, the voice of truth. The symbols thus show how divine things are ordered, the shadow to the light and the sun to the year and the earth to all forms of nature."

54. PGM III, 511; II, 165, 169, Pl I:2; IV, 2708-84; VII, 429-458; LXX, 12-19. For amulets, BONNER, o.c. (n. 39), p. 201; c. BONNER, “Amulets chiefly in the British Museum," Hesperia 20 (1951), p. 344-345; for inscriptions, see the Phalasarna tablet, IC II.xix.7; discussion in R. wÜNSCH, Antikes Zaubergerät aus Pergamon, Berlin, 1905; P. MAAS, "Epeniktos," Hesperia 13 (1944), p. 35-37; D. JORDAN, “The Inscribed Lead Tablet from Phalasarna." ZPE 94 (1992), p. 191-194; D. JORDAN, “Three Texts from Lokroi Epizephyrioi." ZPE 130 (2000), p. 95-103; JORDAN,l.c. (n. 52); C.A. FARAONE,R. KOTANSKY, “An Inscribed Gold Phylactery in Stamford, Connecticut," ZPE 75 (1988), p. 257-266; C. BRIXHE , A. PANAYotou, "Le Plomb magique de Phalasarna IC II - XIX 7," in Hellènika Symmikta. Histoire, Linguistique, Épigraphie II (1995), p. 23-38.

55. GAGER,l.c. (n. 51), p. 34 n. 40; P.C. MILlER, "In Praise of Nonsense," in A.H. ARMSTRONG (ed.), Classical Mediterranean Spirituality, New York, 1986, p. 481-505; F. DORNSEIFF, Das Alphabet in Mystik und Magie, Leipzig/Berlin, 1922, p. 81-82; C.E. RUELLE, "Le chant des sept voyelles grecques," REG 2 (1889), p. 38-44, 393-95; H.D. BETZ, The Greek Magical Papyri in Translation: Vol. one: Texts, Chicago, 1986², p. xlviii.

56. P. FAURE,Fonctions des cavernes crétoises, Paris, 1964, p. 113; Iambl., VP, 17, 25; Porph., VP, 9, 17; D.L., V, 25-27; Justin, 20, 4; Valerius Maximus, VIII, 7, 2; for the marriage of Pythagoras in Crete,

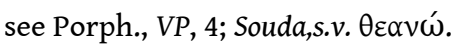

57. BETZ,l.c. (n. 51); H. VERBRUGGen, Le Zeus Crétois, Paris, 1981.

58. FAURE,o.c. (n. 55), p. 114 n. 1.

59. D.L., VP, 3; cf. Xenoph., 21 B 20 D-K; Theopomp., 115 F 67-69 (ed. JACOBY); Maximus Tyrius, 10, 1 ; Epim., 3 B 24 D-K.

60. Corinna, 654, 1, 12-16; scholia to Plato, Symposium, 215e; Diod. Sic., IV, 80; V, 70; IC III, II, 2; scholia to Pi., 0. 42b; Aglaosthenes, 499 F 1c (ed. JACOBY); Dion. Halic., II, 61; Strabo, X, 3, 19; Lucretius, De rerum naturae II, 600-643; Sallust, fr. 3, 67; Vergil, Georgics VI, 149-152; Martial, 9, 16-21; Silius, XVII, 20-24; Lucian, De saltatione, 8; Oppian, Cynegetica III, 7-19; Orphica fr. 210; Arnobius, Adversus nationes III, 41, 43. For Kouretes and Korybantes together, see Eur., Bacchae, 120-141; for Korybantes, Callimachus, Hymnus injovem, 45-53; Strabo, X, 3, 13; Hyginus, Fabulae, 139; Ovid, Fasti IV, 207-214; for Telchines, Germanicus, ad Aratum, 24, fr. c; cf. Diod. Sic., V, 55, the Telchines nurtured baby Poseidon.

61. Porph., Antr., 20; Iamb., VP, 5, 25-27: after Pythagoras' voyage to Crete, he set himself up in a cave near the town of Samos where he spent most of his days and nights, meditating just as did Minos, the son of Zeus. Cf. Hom., Od. XIX, 179, Minos went to the cave and conversed with Zeus 
every year; $c f$. Apollodorus, III, 3, 1, Kouretes as a college of Cretan diviners; Plut., De defectu oraculorum,42, on Koretas at Delphi; Plut., Solon, 12, 7 on Epimenides as the Young Kourete; Zenob., IV, 61 identifies "Kouretic speech" as prophecy; in Euripides' Cretans, fr. 472, Coryphaeus the prophet of Zeus declares himself an initiate of Zeus Idaios.

62. FAURE,o.c. (n. 55), p. 111; Adrasteia in Apollod., I, 1, 6; Ida in Diod. Sic., IV, 60, scholia to Paus. V, 7, 6, schol. to Ap. Rh., I, 1129, Etymologicum Magnum, 465, 26; Anchiale in Ap. Rh., I, 1129-31, Servius, Comm. Virg. Buc. I, 66; Ioannes Lydus, De mensibus IV, 46. Folk etymologies deriving their name from the mother's hand, Stesimbrotos, 107 F 12 (ed. JACOBY); Diom., II, 57, 13; Scholia Hephaest., 158. Equation to Kouretes, Arnobius, Adversus nationes III, 41, 43.

63. H.D. BETZ, "Fragments from a Catabasis ritual in a Greek magical papyrus," HR 19:4 (1980), p. 287-295 and id., Gesammelte Aufsätze I, Tübingen, 1990, p. 147-155; K. PREISENDANZ (ed.), Papyri Graecae Magicae, Stuttgart, 1974, p. 202-03. The text includes the Ephesian letters, and an encounter with a woman named Ereschigal, she who is "holding her thumbs." Pliny identifies the Idaian Daktyloi as thumb-shaped, gray stones from Crete, HN XXXVII, 170; cf. Solinus, Collectiones, 11, 1 and Isidorus, Origines XVI, 15, 12. The Ephesian letters, and a possible pun on the woman's thumbs, offer potential but inconclusive references to the Daktyloi.

64. s. MARINATOS, “Zur Frage der Grotte von Arkalochori," Kadmos 1 (1962), p. 87-95; P. FAURE, "Les minerais de la Crète antique," RA, $7^{\text {th }}$ ser., 1 (1966), p. 45-78; S. HILLER, "Ka-ko-na-wi-jo. Notes on interdependences of temple and bronze in the Aegean Bronze Age," in E. RISCH, H. MUHLESTEIN (eds.), Colloquium Mycenaeum. Actes du sixième Colloque international sur les textes mycéniens et égéens tenu à Chaumont-sur-Neuchâtel du 7 au 13 Septembre 1975, Geneva, 1979, p. 189-195; A. HURST, “À propos des forgerons de Pylos," SMEA 5 (1968), p. 92-96.

65. A.B. KNAPP, Copper Production and Divine Protection: Archaeology, Ideology and Social Complexity on Bronze Age Cyprus, Göteborg, 1986; T. DOTHAN, "The High Place of Athienou in Cyprus," in A. BIRAN (ed.), Temples and High Places in Biblical Times, Jerusalem, 1981, p. 91-95; T. DOTHAN,A. BEN-TOR, Excavations at Athienou, Cyprus 1971-1972, Jerusalem, 1983; V. KARAGEORGHIS, View from the Bronze Age: Mycenaean and Phoenician Discoveries at Kition, New York, 1976; J. COURTOIs, "Le sanctuaire du dieu au lingot d'Enkomi-Alasia (Chypre) et le lieux de culte contemporains en Méditerranée orientale," CRAI (1973), p. 223-294; P. ÅSTRÖM, Excavations at Kalopsidha and Ayios Iakovos, Cyprus, Lund, 1966; H. BUCHHOLTz, “Tamassos, Zypern, 1970-1972," AA Beiblatt zum Band 88, 1973-74, Heft 3.

66. W.H. ENGELS, Kypros: Eine Monographie, Berlin, 1941; S. MORRIS, Daidalos and the Origins of Greek Art, Princeton, 1992, p. 146.

67. The semitic etymology of the Kabeiroi has recently been contested: see R.S.P. BEEKS, "The Origin of the Kabeiroi," Mnemosyne 57 (2004), p. 465-477.

68. KNAPP, o.c. (n. 64).

69. FAURE, l.c. (n. 63).

70. See also Papyrus Graecus Holmiensis V, 40; Isid., Etym. XVI, 13, 5.

71. Hittite An.Bar Ge nepisis, Sumerian AN.BAR, and Egyptian bia'n pet have been translated as "black iron from heaven". J.D. MUHLY, R. MADDIN, T. STECH,E. OZGEN, "Iron in Anatolia," Anatolian Studies 35 (1985), p.67-84; s. KOSAK, "The gospel of iron," in H.A. HOFFNER, G.M. BECKMAN (eds.), Kanissuwar: A tribute to H.G. Güterbock on his Seventh-fifth Birthday, Chicago, 1985, p. 125-136; P. MCNUTT, The Forging of Israel, Sheffield, 1990, p.132; J. WALDBAUM, "The First Archaeological Appearance of Iron and the Transition to the Iron Age," in WERTIME,MUHLY,o.c. (n. 9), p. 69-98; J.K. BJoRKMAN, "Meteors and Meteorites in the Ancient Near East," Meteoritics 8 (1973), p. 91-130. For Greek contexts, see the meteor of Ayia Triadha, S. MARINATOS, "Two Interplanetary Phenomena of

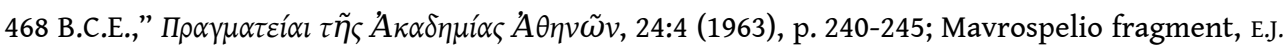
FORSDYKE, "The Mavro Spelio Cemetery at Knossos," ABSA 28 (1926-27), p. 243-296; 277-278; s. 


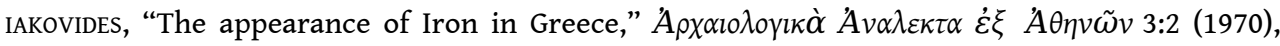
p. 288-292.

72. R.J. FORBES, Studies in Ancient Technology, vol. 9, Leiden, 1972, p. 189, 210; WALDBAUM,l.c. (n. 69); J. PIASKOWSKI, "A Study of the origin of the Ancient High-Nickel Iron Generally Regarded as Meteoric," in T.A. WERTIME, S.F. WERTIME (eds.), Early Pyrotechnology: the evolution of the first fire-using industries: papers presented at a seminar on early pyrotechnology held at the Smithsonian Institution, Washington D.C., Washington, D.C., 1982, p. 237-243; G. VAROUFAKIS, "Investigation of some Minoan and Mycenaean Iron Objects," in Frühes Eisen in Europa: Acta des 3. Symposiums des "Comitae pour la sidérurgie ancienne de l'UISP," Schaffhausen und Zürich, 24-26 Oktober 1979, Schaffhausen, 1981, p. 25-32; G. VAROUFAKIS, "The Origin of Mycenaean and Geometric Iron on the Greek Mainland and in the Aegean Islands," in J.D. MUHLY, R. MADDIN, v. KARAGEORGHIS (eds.), Early Metallurgy in Cyprus, 4000-500 B.C.E., Nicosia, 1982, p. 315-322. All meteors have some iron content, ranging from the siderites, which are $100 \%$ iron and nickel, to stony-iron siderolites, which are $50 \%$ iron and $50 \%$ silicate, and stony aerolites, which are 10-15\% iron and nickel, mixed with $85-90 \%$ silicates. Only one in ten meteors is a siderite; see V.F. BUCHWALD, Handbook of Iron Meteorites: History, Distribution, Composition and Structure, Berkeley, 1975.

73. S. SHERRATT, "Commerce, iron and ideology: Metallurgical innovation in $12^{\text {th }}-11^{\text {th }}$ century Cyprus," in V. KARAGEORGHIS (ed.), Proceedings of the International Symposium,Cyprus in the $11^{\text {th }}$ Century B.C.E., Nicosia, 1994, p. 59-108, p. 64 n. 3; MCNUTT,o.c. (n. 69) p. 135; BJORKMAN,l.c. (n. 69) p. 110, 113.

74. DONOHUE,o.c. (n. 29), p. 5, 219-229.

75. Arsenius in Leutsch, Corpus Paroem. II, 468; C. FARAONE, Talismans and Trojan Horses, Oxford, 1992, p. 14 n. 19 notes that the term baityl, once argued to refer only properly to meteoric stones, is now used to refer to a large class of consecrated stones; cf.F. LENORMANT, s.v. Apyoì $\lambda$ í $\theta o 1, R E$ Band 2 (1896) col. 723-728; G.F. MOORE, "Baetylia," AJA 7:2 (1908), p. 198-208; W. FAUTH, "Baitylia," Kleine Pauly Band 1 (1964), col. 806-808.

76. А.В. Соок, Zeus: A Study in Ancient Religion III.1, Cambridge, 1940, p. 936, and MARINATOS, l.c. (n. 69) suggest the stone should be understood as a meteor, fallen from heaven as was the Delphic stone. Regarding Pausanias, X, 24, 6, J.G. FRAZER, Pausanias' Description of Greece, vol. V, New York, 1965, p. 355 suggests the stone was meteoric. CooK, l.c. and Zeus: A Study in Ancient Religion, vol. I. Cambridge, 1914, p.520-21 notes numerous late authors who define 'Baitylos' as the stone

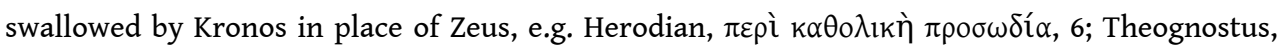

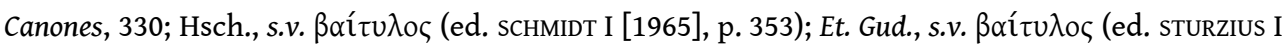

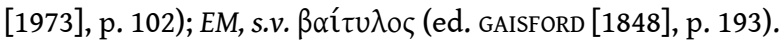

77. Philo of Byblos, 810; 23; Damascius, Vita Isidori, 203. Helenos the seer had a sideritic meteor which he bathed, wrapped in clean garments, and brought to life through the use of spells, in order to hear its prophetic advice; the Orphic Lithica (360-370) promises that anyone who does the same will enjoy the same benefits; for discussion, see соок,l.c. (n. 76) 1940, p. 921-922. The power of meteors to prophesy is most clearly attested in Levantine material, where omen texts from the first and second millennia B.C.E. reflect the prophetic powers of the meteor as a missive from god to men; see BJORKMAN,l.c. (n. 69).

78. A.I. BaUmgarten, The Phoenician History of Philo of Byblos, Leiden, 1981, p. 202; E.D. STOCKTON, "Phoenician Cult Stones," The Australian Journal of Biblical Archaeology 2:3 (1974-75), p. 1-28, p. 27 n. 89; FARAONE,o.c. (n. 73), p. 5.

79. B.G. DIETRICH, The Origins of Greek Religion, Berlin, 1974, p. 92; FAURE,o.c. (n. 55), p. 191; P. WARREN, "Of baetyls," OAth 18 (14) (1990), p. 193-206.

80. FAURE,o.c. (n. 55) p. 109; I. SAKELLARAKIS, “The Idaean Cave. Minoan and Greek Worship," Kernos 1 (1988), p. 207-214; в. RUTKошsкI, The cult places of the Aegean, New Haven, 1986, p. 100; L.V. WATROus, The Cave Sanctuary of Zeus at Psychro, Liège, 1996, p. 58-59; s. BENTON, "The evolution of the 
tripod-lebes," ABSA 35 (1934-35), p. 74-130; L. TYREE, Cretan Sacred Caves: Archaeological Evidence, Ph.D. Dissertation, University of Missouri, 1974, p. 40-43.

81. J.W. SHAW, "Phoenicians in Southern Crete," AJA 93 (1989), p. 165-183.

82. Hom., Od. XXII, 481; XXIII, 50 and Eustathius ad loc.; Pliny, HN XXXV, 177; Virgil, Aeneid II, 698, and Servius, ad loc.; Seneca, Quaestiones Naturales II, 21, 2; II, 53, 2.

83. R. PARKER, Miasma: Pollution and Purification in Early Greek Religion, Oxford, 1983, p. 227; W. BURKERT, Greek Religion, tr. J. Raffan, Cambridge, 1985, p. 76-78.

84. Hom., Il. VIII, 135; XIV, 415; Od. XII, 417; Nonnos, Dionysiaca XXXVII, 63; Persius, II, 25; Lucan,

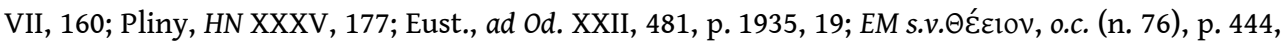
19; Isid., Orig. XVI, 1, 9; H. BLUMNER, “Schwefel," RE III (1923), col. 797.

85. PARKER,o.c. (n. 81) p. 227; NILSSON,o.c. (n. 37), vol. II p. 236; for purification by fire, Porph., De antro nympharum, 15; Serv., Aen. VI, 741; W. BURKERT, Ancient Mystery Cults, Cambridge, 1987, p. 98.

86. Plut., Lysander,12; Pliny, HN II, 149; D.L., II, 12.

87. Call., fr. 100, 104 ff.; Nonn., D. XIV, 38; 37, 164; Ovid, Metam. IV, 281; HEMBERG,l.c. (n. 3), p. 50; U. VON WILAMOWITZ-MOELLENDORfF, "Pausanias-Scholien," Hermes 29 (1894), p. 245; cf.F. JACOBY, "I $\Omega$

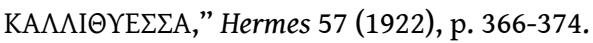

88. Paus., V, 8, 1; 13, 8; 14, 7-9; VI, 21, 6; 23, 3; VIII, 31, 3; IX, 19, 5; 27, 8.

89. HEMBERG, l.c. (n. 3), p. 58.

90. U. VON WILAMOWITZ-MOELLENDORFF, Euripides Herakles (2), Darmstadt, 1909 [1959], p. 34 n. 67.

91. R. ETIENNE, D. KNOEPFLER, Hyettos de Béotie, Paris, 1976 (BCH suppl. 3), p. 178.

92. c. TZAVELlAS-BONNET, "Melqart, Bès, et l'Héraclès dactyle de Crète," Phoenicia and its Neighbors, Studia Phoenicia 3 (1985), p. 235; F. GRAF, Nordionische Kulte, Rome, 1985, p. 315 n. 155.

93. TZAVELlAS-BONNET,l.c. (n. 92); A.M. BISI, "Da Bes a Herakles. A proposito di tre scarabei del Metropolitan Museum," Rivista di studi fenici 8 (1980), p. 19-42; v. WILSON, “The Iconography of Bes in Cyprus and the Levant," Levant 7 (1975), p. 77-103; w. CULICAN, "The Iconography of Some Phoenician Seals and Seal Impressions," Australian Journal of Biblical Archaelogy 1:1 (1968), p. 50-103; C. GROTTANELLI, “Eracle Dattilo dell'Ida: Aspetti 'Orientali'," Oriens Antiquus 11:3 (1972), p. 201-208; E. LIPINSKI, Dieux et déesses de l'univers phénicien et punique, Leuven, 1995 (Studia Phoenicia, 14), p. 380-388.

94. J. BREMMER, "The legend of Cybele's Arrival in Rome," in M. J. VERMASSEREN (ed.), Studies in Hellenistic religions, Leiden, 1979, p. 9-22.

95. M. LAUNEY, Études thasiennes I: Le sanctuaire et le culte d'Héraklès à Thasos, Paris, 1944; J. POUILLOUX, Recherches sur l'histoire et les cultes de Thasos: de la fondation de la cité à 196 avant J.-C., Paris, 1954; J. TEIXIDOR, “L'interprétation phénicienne d'Héraclès et d'Apollon," RHR 200 (1983), p. 243-255; C. BONNET, Melqart. Cultes et mythes de l'Héraclès tyrien en Méditerranée, Namur, 1988 (Studia Phoenicia, 8), p. 346-370, 380-388.

96. LEMONNIER, l.c. (n. 10).

\section{ABSTRACTS}

Classical studies of the Idaian Daktyloi rely on evolutionary and survivalist models which assume prehistoric smiths as the locus of their meaning. More recent anthropologies of technology evaluate technological symbols for their integration of technology into the intellectual, ritual, 
historical and economic structures of the subject culture. A fragmenta incerta of Pherekydes affords a testing-ground for this approach to the Daktyloi. The investigation reveals adaptability and integration into Pythagorean tradition, magical practice, and Cretan history. This offers more cogent reasons for the daimones' longevity than previous models, and corrects the assumption that a fragmentary record reflects cultural insignificance.

Les études classiques sur les Dactyles idéens se fondent sur des modèles évolutionnistes qui donnent sens à ces figures en les associant à des forgerons préhistoriques. Des approches anthropologiques récentes évaluent les symboles technologiques en fonction de l'intégration de la technologie qu'ils opèrent dans les structures intellectuelles, rituelles, historiques et économiques de la culture étudiée. Un fragment incertain de Phérécyde offre une possibilité de tester cette approche des Dactyles. L'étude révèle une adaptabilité et une intégration dans la tradition pythagoricienne, dans la pratique magique et l'histoire crétoise. Cela permet d'expliquer la longévité de ces daimones de manière plus convaincante que ne le faisaient les modèles précédents, et cela corrige l'affirmation qu'un témoignage fragmentaire n'a pas de signification culturelle.

\section{AUTHOR}

SANDRA BLAKELY

sblakel@emory.edu 